\title{
Managing Quality Higher Education in Bangladesh: Lessons from the Singaporean and Malaysian Strategies and Reforms
}

\author{
Mohd. Mohsin ${ }^{1}$ \& Md. Aktar Kamal ${ }^{2}$ \\ ${ }^{1}$ Faculty of Finance \& Banking, International Islamic University Chittagong (IIUC), Dhaka, Bangladesh \\ ${ }^{2}$ Faculty of Management, International Islamic University Chittagong (IIUC), Dhaka, Bangladesh \\ Correspondence: Mohd. Mohsin, Department of Business Administration, Faculty of Finance \& Banking, \\ International Islamic University Chittagong (IIUC), Road 03, House 27, Dhaka 1205, Bangladesh. Tel: \\ 880-017-1687-9886 / 880-017-1178-1188. E-mail: mohsinmdpur@yahoo.com
}

Received: July 11, 2012 Accepted: August 8, 2012 Online Published: October 16, 2012

doi:10.5539/ijbm.v7n20p59 URL: http://dx.doi.org/10.5539/ijbm.v7n20p59

\begin{abstract}
The main purpose of the study is twofold: to get some lessons by examining current strategies, reforms and quality framework relating to quality higher education employed by Singapore and Malaysia and to put forward some policy recommendations to higher educational institutions, governments, policymakers and all other stakeholders of Bangladesh for enhancing the quality in higher education. This study has been conducted mostly based on secondary data by reviewing official publications, both national and international, on quality aspects of higher education of these countries. Published and unpublished research papers, working papers, seminar and conference proceedings, online resources have also been used. In one end, the review findings of this paper show that though the higher education sector of Bangladesh, both public and private, is regulated by the Ministry of Education, there is no legal body in Bangladesh except University Grant Commission to ensure the quality of higher education. In addition to this, this study has also found that there is no accreditation agencies, no accountability system and no academic auditing system in Bangladesh to ensure the quality of higher education though these three key important factors has already been ensured both in Singaporean and Malaysian system of higher of education. It is also observed that a bundle of supportive strategies have been active behind the development of quality higher education of the two countries- Singapore and Malaysia. Finally, the researchers have put some way forward for Bangladesh to be followed to develop the nascent condition of quality in higher education institutions.
\end{abstract}

Keywords: quality, Higher Education Institutions (HEIs), Singapore, Malaysia, Bangladesh

\section{Introduction}

The education, in particular higher education, is one of the most valuable national assets in any country. Higher education is now not treated as luxury product; it is essential to national, social and economic development (Peril \& Promise, 2000). Achieving and sustaining quality in a higher education is a tough challenge for the growing chorus of criticism of higher education system all over the world. Previous literature reveals that quality in higher education (HE) can be and is interpreted in a number of different ways (Cheng and Tam, 1997; Pounder, 1999). Hence, it is real tragedy for the system of higher education that there is still no consensus on how best to measure and manage the quality of higher education.

Quality assurance is the systematic review of educational programs to ensure that acceptable standards of education, scholarship and infrastructure are being maintained (www.unesco.org). The quality of a country's higher education sector and its assessment and monitoring is not only key to its social and economic well-being; it is also a determining factor affecting the status of that higher education system at the international level (UNESCO, 2005). While numerous studies have been conducted to examine the spectrum and factors affecting quality higher education in Bangladesh (Jamal 2002; Andaleeb 2003; UGC 2006; Alam; Ashraf, 2009; Haque, 2011, Monem \& Baniamin 2010; BIISS 210; Islam2011), no studies have been taken to comparatively identify the areas where Bangladesh can take the lessons from the Asian world class giant in global higher education. Motivated by the comments of many researchers, like (Forest 1993, Luke, Peter, Lau \& Gopinathan 2005, UNESCO 2006, S. Susan 2008, Booz, 2008), that other countries, within and outside of Asia, can take a number of key lessons from Singapore for the development of quantity and quality of higher education, this study has 
been conducted to take some lessons for the development of quality higher education in Bangladesh. Malaysia has also set a good example by coping with any problems and challenges that have arisen as it expands its tertiary education system (Hussain, 2004). Besides, the researchers like to mention three different strategic reasons from available literatures why they have selected Singapore and Malaysia as the of cases for reference for the development of quality higher education in Bangladesh; firstly, the education system of these two countries, especially the Singaporean one has historically been based on the stereotype about Asian learners, learning and socio economic priorities at every stages of education driven by the philosophy 'Can Asian think?' rather than blindly following the Western style of education (A Luke et al. 2005); Secondly, the governments of these two countries, with strong commitment to enhance the global competitiveness of their higher education systems, have made attempts to develop their societies into regional hubs of education. Thirdly, these governments have invited foreign universities to set up their campuses to provide more higher education programs in order to attract more students from overseas to study in their countries (or create more educational opportunities for their citizens). The last two reasons are the product of massification and globalization dream of education to be a global school house. The quality of both public and private higher education of Bangladesh have been at so poor stage for which the country is still at the lower bracket, 146th ranked, of human development index in the world with compared to Singapore and Malaysia which are at $26^{\text {th }}$ and 61 th position ( HDI Index, 2011).

In view of the above perspective, this study has been undertaken to achieve two objectives:

i. To examine and compare the current strategies and policies, employed by these three countries to ensure quality in higher education.

ii. To identify some appropriate way outs to higher educational institutions, governments, policymakers and all other stakeholders of Bangladesh for enhancing the quality in higher education

\section{Methodology of the Study}

This study has been conducted by reviewing official publications both national and international, published and unpublished papers, working papers, seminar and conference proceedings, online resources as well as ethnographic observations of the researchers. Lessons from the case studies of Singaporean and Malaysian quality higher education offer an empirical and circumstantial evidence for the development of quality higher education for the competitive strength of Bangladesh in future. About 50 articles from different countries, a number official reports (national and international), and a number of online resources were studied, reviewed retrieved and consulted. Then, the findings were classified thematically to get a picture of quality higher education in Singapore, Malaysia and Bangladesh. Finally, some policy gap has been explored in context of Bangladesh form the lessons learned from the Singaporean and Malaysian experience and some policy suggestions have been forwarded to strengthen the quality higher education in Bangladesh.

\section{Review of Literature}

To examine the issues, status, policies, and reforms taken to boost up the quality in higher education in Malaysia and Singapore, and accordingly their relevancy in the context of Bangladesh, several literatures have been reviewed from several standpoints. We first look at the literature of importance of higher education and the quality spectrum that are used as benchmarking in higher education in general. Then, we look into the literature of the quality issues that have been researched in three sample countries. Finally we review some national and international report on quality higher education.

\subsection{Quality in Higher Education}

Tam (2001) suggested various models for quality in education that include production model which portrays a direct relationship between inputs and output; value added model which weighs the gains achieved by student after receiving the education; and the total quality experience approach that captures the entire learning experience taken by the student during their years in universities and colleges. Five industrial definitions of quality (Garvin, 1984) can be interpreted for higher education as: transcendent quality, where the educators can be treated as producers who provide expert training and professional standing; manufacturing-based quality in which the college or university is the manufacturer and as such, it decides what to produce, when, and how well; Product-based quality; value-based quality which resemblances value when the product (education in this case) performs at or above expectation compared to its cost; user-based quality which defines the quality of higher education by the customer's needs, wants, desires, and preferences.According to World Bank (2007), a broad range of factors affect quality in tertiary institutions including their vision and goals, the talent and expertise of the teaching staff, admission and assessment standards, the teaching and learning environment, the employability 
of its graduates (relevance to the labor market), the quality of the library and laboratories, management effectiveness, governance and leadership. Gibbs \& Zopaitis (2009) researched two different provision of quality for higher education: the student and teaching staff perceptions. The student evaluated quality in terms of the courses, programs, teaching and learning of the higher education institutions. The teaching staff evaluated the quality on the basis of teaching and learning facilities and student examination and assessment topicality. According to the Higher Education Quality Council (HEQC, 1995), in order to produce high quality graduates all degree program should include the aspects listed below: Teaching should be research-informed so that the students may become research-aware; Students should be encouraged to develop self-motivating study habits and skills. There should be an emphasis on the development of a critical and analytical approach to the theories and concepts learned; Students should grasp the impermanence and open-ended character of a discipline's share of, and contribution to, knowledge and understanding; Program should be provided to equip students with the necessary skills to join professional practice, including both intellectual and practical skills. Quality refers to the four pillars of education: learning to know, learning to do, and learning to live together and with others, and learning to be (Delors, 1996). Quality Assurance is a multifaceted problem, further augmented by the number of parties interested in it and the multitude of their respective concerns such as quality as fitness for purpose, quality as compliance( zero errors), quality as customer satisfaction, quality as value for money, quality as enhancement, quality as excellence, quality as transformation, quality as Control (EAU,2006). One of the most clearly defined sets of dimensions of quality for HEIs has been identified by Harvey and Knight (1996), who argue that quality can be broken down into five different but related dimensions: Quality as exceptional (for example, high standards); Quality as consistency (for example, zero defects); Quality as fitness for purpose (fitting customer specifications); Quality as value for money (as efficiency and effectiveness); Quality as transformative (an ongoing process that includes empowerment to take action and enhancement of customer satisfaction).

\subsection{Quality Management Model Used in Higher Education: An International Perspective}

Many countries have national organizations with responsibility for the management of quality within HEIs. For example, within the US, for more than 100 years the accreditation system, three types of accreditation systems namely Regional, National, and specialized, has been used as the primary gatekeeper for defining and assuming quality in the delivery of higher education system (S. Vickie). In the UK, the role of the Quality Assurance Agency (QAA) is to inspect, audit and report on the quality procedures within institutions (www.qaa.ac.uk). Similarly, the Australian Universities Quality Agency (AUQA) has been established to monitor, audit and report on quality assurance in HE (www.auqa.edu.au).

In India, the National Policy on higher education of 1986 is used to monitor the higher education system which does consider the five principles goals for quality higher education, including Greater Access, Equal access (or equity), Quality and excellence, Relevance and promotion of social Values, based on the vision of Radhakrishnan and Kothari Commission(www.ugc.ac.in).

U.S. Department of Education (2006) has pointed out that to contain the ingredients of quality a higher education instituting or program must contain the following qualities: institution's mission, Curricula, Faculty, Facilities, equipment, and supplies, Fiscal and administrative capacity as appropriate to the specified scale of operations, Student support services, Recruiting and admissions practices, academic calendars, catalogs, publications, grading, and advertising, Measures of program length and the objectives of the degrees or credentials offered, and Record of student complaints received by, or available to, the agency

There is general agreement on the four types of performance indicators of quality such as Input, Process, Output and Outcome (Borden, \& Bottrill, 1994; Carter, Klein \& Day, 1992; Cave, Hanney \& Kogan, 1991; Richardson, 1994). These can be more broadly categorized as quantitative and qualitative indicators. Quantitative indicators include input indicators like human, financial and physical resources involved in supporting institutional programs, activities and services while output data reflects the quantity of outcomes produced, including immediate measurable results, and direct consequences of activities implemented to produce such results (Burke, 1998). Qualitative indicators include outcome indicators and process indicators. Outcome indicators focus on the quality of educational program, activity and service benefits for all stakeholders. These key stakeholders include students, parents, the community, employers and industry (Burke, 1998; Warglien \& Savoia, 2006). Process indicators are those which include the means used to deliver educational programs, activities and services within the institutional environment (Burke, 1998).

\subsection{Quality Management Used in Higher Education: A Bangladesh Perspective}

Though Thirty-nine years have passed since the emergence of Bangladesh as a free nation, but no Education Policy has been put to implementation (National Education Policy of Bangladesh, 2010). Available studies 
depicts that several education commissions and report, namely Dr. Qudrat-e Khuda Education commission 1971; Shamsul Haque Education Committee in 1997; Dr. M. A. Bari Commission in 2002; Mohammad Moniruzzaman Mia Commission 2003, Prof. Kobir Chowdhury commission 2009, were taken for the development of quality of total education system . But it has been irony of Bangladesh that the recommendations forwarded by those committees have been kept to the shelves mainly because of politicization of the recommendations. For the first time in 2006, University Grant Commission (UGC) of Bangladesh prepared a 20 year long strategic planning for higher education with the help of World Bank. Higher education in Bangladesh was imparted through public institutions until 1990s up to which its supply situation was much slower (Alam et al, 2007). In 1992, the government of Bangladesh approved the Private University Act (PRUA) that encouraged the private entrepreneurs to establish private universities in Bangladesh. Currently there are 31 public universities and 51 private universities in Bangladesh (BANBEIS, 2009). Conferring so much socio political powers to teachers, the students and other stakeholders, who have converted the public universities in to a field of politics rather than producing professional and innovators as per the needs of country, can be blamed for deterioration of quality higher education in Bangladesh (Alam et al, 2007). Research findings also show that though the Ministry of Education (MoE), an apex policy making body of Bangladesh, regulate and coordinate different plans and programs of public and private higher education with the assistance of UGC, Bangladesh, the public universities are run by senate, syndicate headed by vice chancellor, Faculty Deans, Academic council and finance committee all of whom do have very active linkages with government in power and are appointed and fired according to the whim of the parties in power. This style of managing the public universities in Bangladesh has totally damaged the accountability and quality assurance of higher education (Alam et al, 2007). Till today, there is no legal body except a weak supervision, like reporting to government, of UGC, Bangladesh, to ensure the quality of higher education in private universities as the private universities do not receive any fund from the UGC (Alam et al, 2007).UGC reports (2006) and assessment found that both public and private universities suffer from quality problem in Bangladesh with the exception of a few. The report also mentioned for: the faculties both in public and private actors do not have necessary credentials, the quality of student is so poor, a large number of private universities to provide minimum physical infrastructure, full time faculty, libraries, teaching aids and so on. Critically mentioning the quality assurance of public and private higher education is confined to a certain areas: admitting students, approving courses, courses and panels of examiners, opening new departments, and sanctioning additional teaching posts etc (Alam et al, 2007). Andaleeb (2003) focused nine critical factors to revitalize quality of higher education. Factors are; teacher quality, method and content, peer quality, direct facilities, indirect facilities, administrative efficacy, political climate, gender effects and expected satisfaction with higher education.

\section{Findings: Lessons Learned from the Policies and Strategies in Singapore and Malaysian Higher Education System}

In the past few decades, these two countries have initiated varieties of generic strategies as well as quality specific strategies for the development of total education and higher education system both at national and transnational arena. As because policies of quality education at higher level in any country is not isolated from the polices of total education system and the other policies of national development plan, this research has been conducted in such a manner that it can pick out some elegant elements of general reforms as well quality specific practices of education sector of these two countries.

\subsection{Some Land Mark Reforms}

Singapore has taken some four hallmark policy reforms to develop its Education System (A. Luke et al 2005): Towards Excellence in Schools in 1987; Thinking Schools Learning Nation (TSLN), the first Master plan for IT in education, in 1997; Review of Junior College/upper Secondary Education in 2002; The IT Master plan 2 ongoing since 2003. These reforms had different dimension which contributed the development of education of Singapore to current stage of development. On the other end, Malaysian government has taken four distinct phases in its Higher Education Strategic plan (MOHE in Malaysia, 2007). The phases are: Phase 1- Laying the foundation (2007-2010), Phase 2- Strengthening and Enhancement, Phase 3 - Excellence, and Phase 4- Glory and sustainability (beyond 2020).

\subsection{Recent Reforms HEIs}

The Singapore government has set up an international academic advisory panel, comprising prominent scholars from international higher education institutions and community leaders from big corporations, aimed to help it in establishing a world-class higher education system (Ministry of Education Singapore, 2001). The second stage of higher education reforms saw the establishment of Singapore's third university, the Singapore Management 
University in August 2000. This privately owned institution was formed in collaboration with the Wharton School of Business at the University of Pennsylvania, which has intended to stir up certain degree of internal competition among the existing public-funded universities (Lee and Gopinathan 2001). The third stage of higher education reforms is closely related to the government's review efforts on university governance and funding in 2000 (MOE Singapore 2000). The government of Malaysia has taken seven clear and longer vision to make the HEIs as a top class of the world and to respond the global challenges in international higher education (Malaysian Higher Education Strategic plan, 2020): widening access and quality, improving the quality of teaching and learning, enhancing research and innovation, strengthening institution of higher education, enculturaization of lifelong learning, and reinforcing the higher education delivery system. "My Brain 15" initiative by the government of Malaysia is another bold step to crate $100000 \mathrm{PhD}$ holders by 2020 (OECD, 2011).

\subsection{Research Based Higher Education Policy and Investment on HE}

The expenditure on basic research in the HE sector of Singapore increased from $\$ 115.1$ million ( $34 \%$ ) higher education expenditure on research and development ( HERD) in 2000 to $\$ 462.4$ (54.1\% of HERD in 2009 (Singapore Agency for Science, 2001 to 2009). The level of commitment for research for Centre for Research in Pedagogy and Practice (CRPP) was S\$48 million over a five-year initial period—or, by local calculations, more than 10 times the per capita investment in educational research of the UK, Australia or Canada (A. Luke et al, 2005). Singapore and Malaysia spends $28.9 \%$ and $33.9 \%$ of GDP per capita for the development higher education (Global Competitiveness Report, 2011). As per the Third Outline Perspective Plan, the Malaysian government has given four public universities, USM, UM, UPM, UKM, the status Research University (RU). USM was further selected in 2008 as APEX University in Malaysia which are supposed to enjoy greater autonomy, in governance, finance, in admission and prioritized in infrastructural investment. This university is then supposed to be adequately endowed and empowered, so as to achieve world-class status and be included as one of the top 100 in global university rankings by 2013, and a member of the top 50 by 2020 ( MOK, 2011).

\subsection{Treating higher education policy and institutions as National Development Plan and National Assets}

The Singaporean Government on various occasions has stated that the university education cannot be divorced from economic goals. The universities in Singapore have been assigned to achieve demarcated goals: provide top level professionals managers, planners, and researchers; raise the intellectual tune of society, acting as a bench mark in maintaining higher education, creating wealth (UNESCO, 2006). In 1996, the than prime minister announced governments intention to turn Singapore in to Boston of East Asia (Goh, C.T. 1996). In Malaysia, the national government has seen fit to steer higher education policy and incorporate it in national development plan that is in direction in the national interest (Morshidi, 2010).

\subsection{Corporatizations of HEIs}

In January 2005, based on recommendations raised by the Steering Committee to Review University Autonomy, Governance and Funding, the government of Singapore decided to grant NUS and NTU further autonomous powers by incorporating them as not-for-profit companies (MOE Singapore, 2005) and accordingly they would accountable for their performances (MOK,2011).In 1998, University of Malay, the oldest university in Malaysia, was incorporated along with eight other public universities in the country and accordingly they have become more self-financing, especially when they become allowed to borrow money, enter into business ventures, establish companies and consultancy firms, as well as acquire and hold investment shares. In short, these incorporated universities are now expected to raise funds through all sorts of channels (Lee 1999).

\subsection{Greater Autonomy in HEIs}

National University of Singapore (NUS) and Nanyang Technological University (NUT) - had to adhere to the principle of greater accountability to ensure an efficient and effective way of spending public funds. Among others, these universities could now recruit and reward their staff according to their performance in terms of productivity and quality, so as to foster a vibrant entrepreneurial climate within the institutions (MOE Singapore 2000).The Malaysian government has decided to give autonomy to all public universities in certain areas for awarding academic freedom except the financial matters with accountability (Morshidi, 2009). At this juncture, it is significant to define university autonomy or freedom as "the necessary degree of independence from external interference that the University requires in respect of internal organization and governance, the internal distribution of financial resources and the generation of income from public sources, the recruitment of staffs, the setting of the conditions of the study and, finally, the freedom to conduct teaching and research" (International Association Universities 1998). 


\subsection{Quality Assurance Mechanism and Accreditation Bodies}

The MOE of Singapore maintained the sole responsibility to uphold the quality of private education. This includes checking the curricula, entry requirement and academic rigor (MOE, 2009). The ISO 9000 standard was taken as popular standard of promoting quality, transparency and consistency among the private school (Yeo, 2008). In December 2004, the Economic Development Board (EDB) of Singapore developed a new framework called 'Singaporean Education Excellence Program' consisting of three key components: academic excellence, organizational excellence, and student protection and welfare, for measuring the quality of private higher education providers (SPRING, 2004). After education excellence program, three new quality assurance mechanisms were introduced; the Singapore Quality Class for Private Education Organization (SQC for PEOs) scheme, the CASE (consumer association for Singapore) trust for education scheme and the new established New Regulatory Regime (Lim, 2011). The SQC for PEOs has been based on seven dimensions (CASE Trust Department, 2008): leadership, planning, information, people, process, customers, and result using an instrument known as the Business Excellence Assessment for continuous improvement (BEACON). To regulate all activities and to increase the efficiency of higher education institution the government of Malaysia established National Accreditation Board (LAN) in 1998 with a view to formulating policy for the standard of quality control of educational programs, monitoring, reviewing, and overseeing the quality of educational program, accrediting the courses offered and advising and recommending to the ministers for his approval of courses (Education Guide Malaysia, 2006). The Quality Assurance Division (QAD) of the MoHE was established in 2002 to promote public confidence in the quality of public university and public colleges (Ali et al, 2011) as a guide of quality assurance practices that includes: 1) vision, mission, and objectives; 2) design of the education program; 3) student assessment; 4) student selection and support system; 5) educational resources; 6) programs evaluation; 7) leadership and government and continuous leadership. A rating System for Malaysian Higher Education Institution ( SETARA) was introduced in 2007 to enhance quality and best practices among public universities ( OECD, Malaysia Country profile 2011).

In addition, Malaysian Ministry of Higher Education (MOHE), which was under the Malaysia MoE, was established in 2004 with a motive to improve, strengthen and develop the quality of tertiary education (MOK 2011). A unified quality assurance structure that covers both the private and public higher education institutions, the Malaysian Quality Framework (MQF) was adopted in 2004, and the framework has become even more centrally controlled after the founding of Malaysian Quality Agency (MQA) which is a merger of LAN and the quality assurance division of the MOHE and responsible for the implementation of MQF (Fahmi, 2008).

The MQA's developmental approach and the design of code of practices main objective are to assist the higher education providers to enhance its academic performance and institutional effectiveness. Key among this, are the Code of Practice for Program Accreditation (COPPA) and Code of Practice for Institutional Audit (COPIA). The Codes prescribed quality standards and criteria in the nine areas for evaluation and it covers i. Vision, mission, educational goals and learning outcomes; ii. Curriculum design and delivery; iii. Assessment of students; iv. Student selection and support services; v. Academic staff; vi. Educational resources; vii. Program monitoring and review; viii. Leadership, governance and administration; and ix. Continual quality improvement (Fahmi, 2008).

In general, the MQA quality assures program through three distinct processes: i. Provisional Accreditation - this is an initial process which will help higher education providers to achieve the accreditation by enhancing the standard and quality set in the provisional accreditation evaluation. ii. Accreditation - this is a formal recognition that the certificates, diplomas and degrees awarded by higher education institutions are in accordance with the set standards. iii. Audits - Audits may be conducted for program maintenance, academic performance audit, thematic, program, faculty or institutional level (Fahmi, 2008).

The main role of the MQA is to implement the Malaysian Qualifications Framework (MQF) as a basis for quality assurance of higher education and as the reference point for the criteria and standards for national qualifications. The MQF was developed to unify and harmonies all Malaysian qualifications. Other functions include: To develop standards and criteria and all other relevant instruments as national references for the conferment of awards with the cooperation of stakeholders; To quality assure higher education institutions and programs; To accredit courses that fulfill criteria and standards; To facilitate the recognition and articulation of qualifications; and To maintain the Malaysian Qualifications Register (MQR) (Fahmi, 2008).

\subsection{Teacher Development Strategy}

Singapore system of education provides some key ideas to consider for any developed or developing country (S. Susan, 2008). National Institute of Education (NIE) of Singapore provides high standard of preparation and deep support to the teachers who are categorically selected from the top third of graduating class and teacher entrance 
proficiency exam. The Ministry of Education looks and finds for only those young people as teachers who have a passion for helping others. Professor at NIE provide coaching, counseling and support to the teacher candidates. Singapore developed a system called Enhanced Performance Management System (EPMS) through which teachers are encouraged to expand their teaching repertoire. Teacher candidate entering the NIE receive a stipend and all teachers in Singapore are given opportunities to attend more than 100 hours of additional training and courses every year. Singapore offers a wide range strategic financial reward to the teachers: first, teachers get annual bonuses up to $10 \%-30 \%$ based on their EPMS performance; second, teachers are given $\$ \$ 400-700$ per year to take foreign language or computer training, buy software, join a professional organization, subscribe to journal. In addition, Singapore has taken a long term retention fund, $\$ \$ 3,200-6200$ per year, named CONNECT(Continuity, Experience and Commitment) to demoralize the movements of teacher s from one career to another.

In Malaysia the ministry, through the Teacher Education Division (TED) is directly involved to provide basic pre-service as well as in-service teacher training programs. The main objectives of the TED are: a) train teachers of high caliber to fulfill the requirements of all educational institutes within the national educational system; b) consistently upgrade and update the knowledge, competency and efficiency of trained teachers and lecturers in both academic and professional areas; c) develop teacher training college as centers of excellence (World Data on Education, 2010/11).

\subsection{University - Industry- PRI (Public Research Institute) Linkage}

The universities in Singapore and Malaysia have been able to maintain a credible and sustainable relationship with industries for collaborating and commercializing their research and development products and ideas. Singapore holds $6^{\text {th }}$ position whereas Malaysia holds 21 th position in the world (Global competitiveness report, 2011-12) in maintaining this undeniable factor for quality education. Moreover, the Malaysian government emphasized this important indicator in the $9^{\text {th }}$ Malaysian plan (A Lawrence at el 2009). In Singapore, 52.5\% and $50.8 \%$ of manufacturing and service firms had collaborated with HEIs and governments, PRIs respectively (Wong et al 2006).

\subsection{Transnational HE Initiative}

To tap in the lucrative education market more aggressively, the Singapore government had launched its Global Schoolhouse initiatives in 2002 (MOK, 2011): the government of Singapore has taken efforts by its Economic Development Board instead of its MOE, to strategically invite world-class and reputable universities from abroad to set up their Asian campuses in the city-state. As a result, Singapore is today home to 16 leading foreign tertiary institutions and 44 pre- schools offering international curricula. The prestigious Institute European' Administration des Affaires (INSEAD) established its Singapore branch campus in2000, the University of Chicago Booth School of Business (2000), S.P. Jain Center of Management (2006), the New York University's Tisch School of the Arts (2007), and DigiPen Institute of Technology (2008) are among the list of these foreign tertiary institutions, ranging impressively from business, management arts, media, hospitality to information technology, biomedical sciences, and engineering.

\subsection{Joint-degree Program}

Local Singapore universities are actively collaborating with peer universities across the world in a diversified spectrum of academic programs, bringing together affluent resources in such fields. Students are given freedom to study at both campuses, and receive supervision and teaching of faculties from both universities. It can be mentioned that the Singapore-MIT Alliance (SMA), an innovative engineering education and research enterprise jointly founded by the NUS, the NTU, and the Massachusetts Institute of Technology (MIT) in 1998 (MOK, 2011). This alliance has so far developed five graduate degree programs, and has created a distant learning environment at the forefront of current technology. And finally, as part of its policy to support transnational higher education, the Singapore government also offers a comprehensive package of financial aid to international students through several public channels (Cheng, Ng, and Cheung 2009).

The Malaysian governments has also been working closely with overseas partners, (including multinational corporations) to set up branch campuses, twining programs namely ' $2+1$ ' or ' $1+2$ ', meaning that first digit for study of local college and second digit for study with overseas twining university and establishing foreign campuses (Goi, 2009). Study shows that 19 UK universities and 18 Australian universities are currently operating 110 and 71 twinning program in Malaysia respectively (MOK, 2011).

\section{Discussions}

It has been clear from the findings of this study that a bundle of supportive strategies have been active behind the 
development of quality higher education of the two countries- Singapore and Malaysia. It is also crystal clear that that gaining competitive advantage in quality higher education sector depends not only higher education related strategies but also it is a matter integration of other polices like timely reforms, strong transnational education policies, merging national economic policies with education policies, research and development polices, innovation policies, and human development policies of a country and so on. Moreover, it can also be mentioned from the findings that ensuring quality at higher education is the combination of public and private sector of higher educational institutions and other stakeholders of relating to education.

To flourish the stage of quality education in Bangladesh, the Ministry of Education, with the assistance of the World Bank, has undertaken a Higher Education Quality Enhancement Project (HEQEP) planned to prepare students at tertiary level specially the university graduates in such way that they can successfully compete in the context of international knowledge society (http://www.heqep-ugc.gov.bd). The Higher Education Quality Enhancement Project (HEQEP) consists of four components: Academic Innovation Fund (AIF), Higher Education Management Information System (HEMIS, Bangladesh Research and Education Network (BdREN) and Project Management (PM). AIF is a fund designated to be awarded to participating public and private universities as non-refundable grant to promote innovative proposals for quality enhancement; BdREN will be a high-speed data-communications network that is independent of the commercial internet which is connected to several international research communities in Asia Pacific, Europe and North America, via the Trans-Eurasia Information Network 3 (TEIN3) and Internet2 and is dedicated to meeting the needs of the academic and research communities of both public and private sectors connecting Malaysia, China, South Korea, Japan, Thailand, Vietnam, Philippines, Singapore, Indonesia, Australia, Europe and the United States; Higher Education Management Information System (HEMIS) will be established to achieve: (i) storing data related to different managerial and academic aspects of the universities (student admissions, students' performance, curriculum, lectures, alumni, academic staff, students' social affairs, etc.) (ii) supporting administrative and managerial information flows, and (iii) providing institution management and various academic and non-academic departments with timely and reliable information. HEMIS will be developed in two phases: a national level HEMIS (N-HEMIS) and a university level HEMIS (U-HEMIS). A draft regulation is under consideration by the Ministry of Education of Bangladesh to accommodate the Cross Border Higher Education (CBHE) providers within a legal framework.

\section{Way Forward: Some Policy Suggestions for Bangladesh}

Our research findings show that Bangladesh is still lagging behind Singapore and Malaysia almost in every areas relating to educational status and other relevant significant policy areas. At this point it is significant to mention that the position of Bangladesh 137th in the world as per knowledge economy index where as Singapore and Malaysia are holding 20 th and $65^{\text {th }}$ position in the world respectively (kam 2012 www.worldbank.org/kam). Hence, this research article has identified some policy measures that Bangladesh can apply to develop its nascent stage of quality of higher education institutions and to promote the brand of its higher educational product, services, market and institutions even to abroad.

First, Bangladesh should take some sustainable educational reforms program like Singapore and Malaysia not only for higher education sector but also for every stage of education say for primary, secondary and tertiary level and implement them as piecemeal basis.

Second, it can be suggested that to draft and to implement the plan, the higher education policy makers, scholars and entrepreneurs of Bangladesh can exchange views and ideas with the policy makers, scholars and thinkers of higher education of Singapore and Malaysia by physically visiting or by arranging seminars and conferences in this regard with joint collaboration of public, private and other stake holders of education of these three countries.

Third, the Government of Bangladesh should allocate a greater proportion of national budget behind total education sector as well as tertiary level of education. As compared to Singapore and Malaysia, the budgetary allocation is not so competitive. Bangladesh spends only $2.4 \%$ of GDP on total education system whereas Singapore and Malaysia spends $3.3 \%$ and $4.1 \%$ of GDP respectively (Global Education Digest, 2011, UNESCO). Besides, Singapore and Malaysia spends $28.9 \%$ and $33.9 \%$ of GDP per capita for the development higher education.

Fourth, Bangladesh should some bold step to patronize the university faculties to contribute more on research activities along with their academic assignments. It can follow Singapore by establishing a Center for Research and Pedagogy and Practice (CRPP) and can also adopt the Malaysian polices to establish Research Universities and Apex universities which will be a milestone for the improvement of quality education. 
Fifth, the public policy makers of Bangladesh must integrate the education policies with national development policies while drafting national development plans. The curricula of higher education system must reflect those priorities set in education and national development plan to develop a persistent human recourses of the country. As mentioned earlier in this paper, both Singapore and Malaysia has proved them fitter in this aspect.

Sixth, corporatizing the public universities can be a commendable step to take for Bangladesh as Singapore and Malaysia has already done it. By corporatization, they can become more self-financed, can borrow money from elsewhere, enter into business ventures, establish companies and consultancy firms, as well as acquire and hold investment shares.

Seventh; giving greater autonomy along with accountability to public universities of Bangladesh can ensure quality education at higher education institutions. This research has investigated that the Singaporean and Malaysian government has adopted this strategy in some leading public universities. This is extremely necessary to make sure that the public universities in Bangladesh are enjoying full degree of independence from external interference with accountability of the concerned authorities.

Eighth, the government of Bangladesh must take some herculean strategies and legal frameworks in order to assure quality of higher education through assessment, academic audit and accreditation of public and private higher education institutions and their overall academic activities as it has no external system or agency until now to review the academic program. This study has found that Singapore established SQC and BEACON quality framework whereas Malaysia has established MQA, MQF and MQR for the accreditation purpose of public and private higher education institutions.

Ninth, the collaboration and partnership among universities, industries and public research institutes in Bangladesh is still its rudimentary stage which is $126^{\text {th }}$ position in the global rank (Global competitiveness report, 2011-12). This issue should seriously be considered by the policy makers of public and private higher education institutions to upgrade the quality of higher education.

Tenth, the quality of teachers of Bangladesh at all level- primary, secondary, and tertiary level- must be improved. Bangladesh can follow the lesson of Singaporean Teaching Development Model to create strong sense of professionalism among the teachers.

Lastly, our research suggests that Bangladesh can take necessary policy framework for establishing some quality higher education institution for tapping the lucrative opportunities in the market of Cross Border Higher Education. Like Singapore and Malaysia, it can initiate to offer Joint degree program or twining program with world class universities of the West and East. It will give twofold benefits to Bangladesh: it will be able to save a lot of foreign currencies that very year flows out from the country as a lot of student moves out aboard in search of quality degree. Then, higher education sector will be considered as export oriented industry if foreign students come in Bangladesh in search of quality degree.

\section{Conclusions}

Defining and measuring quality in higher education and comparing quality across nations in the broader meaning of the term is a more or less impossible task (Liv \& per 2010). Like any other country around that world, it is also a tough challenge for Bangladesh to achieving and sustaining quality in higher education. Although there is no single recipe for managing and measuring quality education in higher education, the policy suggestions outlined in this study represent some important lessons for Bangladesh from the Singaporean and Malaysian Model. Using Singapore models, many developed and developing courtiers are garnering the quality of education and its reforms. Hence, Bangladesh is also not an exception. It is expected that, if these policy suggestions are followed holistically, should Bangladesh increase the likelihood of quality education not only at higher level but also at every level of academia. The researchers like to conclude that it will be wise for Bangladesh to select and implement those priorities which seem to be strategically fit as per ability of Bangladesh rather than blindly mimicking the Singaporean and Malaysian Model. The implementation of the above suggestions would require a concreted and harmonious efforts by the Bangladesh government, HEIs both public and private, industrial sectors, educationists, international education donor agencies and the support by the mass people as a whole.

\section{References}

Alam, G. M., \& Khalifa, M. T. B. (2009). The impact of introducing a business marketing approach to education: A study on private higher education in Bangladesh. Afr. J. Bus. Manager, 3(9), 463-474. 
Alam, G. M., Hoque, M. S., \& Siddiqui, S. F. (2007). Private higher education in Bangladesh. Research paper, Paris, International Institute for education plan.

Ali, N., Isa, M. Z., \& Ibrahim Dhalia. (2011). International Conference On Society and Economic Development, IPEDR, 10(2011). Singapore: IACSIT press.

Andaleeb, Syed Saad. (2003). Revitalizing Higher Education in Bangladesh: Insights from Alumni and Policy Prescriptions. Higher Education Policy, 16(4). http://dx.doi.org/10.1057/palgrave.hep.8300036

Ashraf, M. A., Ibrahim, Y., \& Joarder, M. H. R. (2009). Quality Education Management at Private University in Bangladesh: An exploreatory study. Journal Pendidik dan. Jo, 24, 17-32.

Bangladesh Bureau of Education Information \& Statistics. (2009). Bangladesh Education Statistics.

Bangladesh Institute of International and Stretegic Studies (2010). Eminent Person's Lecture Programme on Education in Bangladesh: Present Status, Challenges and Future outlook. Dhaka.

Booz, A., \& Hamilton. (2008). How to Succeed at Education Reform: The case for Saudi Arabia and the Broader GCC Region. Ideation Center-Insight.

Borden, V., \& Bottrill, K. (1994). Performance Indicators; Histories, Definitions and Methods. New Directions for Institutional Research, 82, 5-21. http://dx.doi.org/10.1002/ir.37019948203

Burke, J. C. (1998). Performance Funding: Arguments and Answers. New Directions forInstitutional Research, 97, 85-90.

Carter, N., Klein, R., \& Day, P. (1992). How organizations measure success: the use of performance indicators in government. London: Routledge.

Case Trust Department, Singapore. (2008). Case trust for education information and application kit. Singapore: Case Trust Department.

Cave, M., Hanney, S., Henkel, M., \& Kogan, M. (1997). The Use of Performance Indicatorsin Higher Education: The Challenge of the Quality Movement (3rd ed.). London: Jessica Kingsley.

Cheng, Y., \& Tam, W. (1997). Multi-Models of Quality in Education. Quality Assurance in Education, 5(1), 22-31. http://dx.doi.org/10.1108/09684889710156558

Cheng, Y., Ng, S. W., Chenung, A. P. L., Tang, Y. F., \& Yuen, W. Y. (2009). A Technical Research Report on the development of Hong Kong as a Regional Education Hub. Hong Kong institute of education, Hong Kong.

Delors, J. (1996). Learning: The Treasure within Paris. UNESCO.

Economic Development Board. (2004). Singapore set to Become Global Schoolhouse. Ecomomic Development Board Singapore, Singapore.

Education Guideline Malaysia. (2006). National Education System: Higher Education Level-An overview of Higher Education System. Education Guideline Malaysia $\left(10^{\text {th }}\right.$ ed. pp. 299-308). Petaling Jaya, Selangor: Challenges concept(M).Sdn.Bhd.

European University Association. (2006). Quality culture in European universities: a bottom-up approach. Report on the three rounds of the Quality Culture Project. Brussels: EUA asbl

Fahmi, Z. H. M. (2008). Quality Assurance in Malaysian Higher Education. Proceedings of the ASEAN Quality Assurance agencies Roundtable Meeting, Kuala Lumpur, Malaysia.

Gibbs, P., \& Zopaitis, A. (2009). An exploratory use of the stakeholder approach to defending and measurimg quality: The case of Cypriot higher education institution. Quality in Higher Education, 15(2), 147-165. http://dx.doi.org/10.1080/13538320902995774

Global Competitiveness Report. (2010). Human Development Index. Retrieved from $\mathrm{http}: / /$ www.inthezone.com/pdfs/GCR

Goh, C. T. (1996). NUS and NTU must aim to become world-class. Universities speeches, 20(5), 14-18.

Goi, C. L., \& Goi M. T. (2009). Rebranding of higher education institutions in Malaysia. International journal of Business \& Management, 4(9), 170-177.

Gravin, D. A. (1984). What does product quality mean? Sloan Management Revalue System, 26, 25-43.

Haque, H. M. J., Das, D., \& Farjana, R. (2011). Satisfaction of Student Services in Tertiary Level: Perspective Bangladesh. European Journal of Social Science, 19(2). 
Harvey, L., \& Knight, P. T. (1996). Transforming Higher Education. Buckingham: SRHE and The Open University Press.

HEQC. (1995a). Quality enhancement group: what are graduates? Clarifying the attributes of 'graduateness'. London, Higher Education Quality Council. Retrieved from http://www.city.londonmet.ac.uk/deliberations/graduates/ starter.html

Hussain, S. (2004). Education in Malaysia, Education in Malaysia: History, System and Philosophy. Kuala Lampur.

Islam, Y. (2011). Tertiary Education in Bangladesh-Brief History, Problem and Prospects. International journal for the scholarship of Teaching and Learning, 5(2). Georgia Southern University.

Jamal, Shawkat A. N. M. (2002). Role of Private Universities in Human Resource Development.

Lawrance A., Ismail, M., Ahmad, A., \& Jamailah O. (2009). Background of Malaysian Private Institutions of Higher Learning and Challenges faced by academics. The journal of International Social Research, Malysia.

Lee, M. (1999). Private higher education in Malaysia. Pulau Pinang: Pusat Pengajian IIMU Pendidikan USM.

Lee, M. H. H., \& Gopinathan, S. (2001). Centralized decentralization of higher education in Singapore. Education and Society, 19(3), 79-96.

Lim, C. B. (2011). Australian Transnational Higher Education Quality Assurance in Singapore and Malaysia. A thesis paper, BBA, Deakin University Malaysia.

Liv Anne S., \& Per Olaf A. (2010). The Quality of Higher Education and Employabilty of Graduates. Quality in Higher Education, 16(3), 297-313. http://dx.doi.org/10.1080/13538322.2010.506726

Luke, A., Peter F., Shun L., \& Gopinathan S. (2005). Towards Research-based Innovation and Reform: Singapore schooling in transition. Asia Pacific Journal of Education, 25(1), 5-28. http://dx.doi.org/10.1080/02188790500032467

Ministry of Higher Education Malaysia. (2007). The National Higher Education Strategic Plan - Beyond 2020 (Pelan Strategic Pengajian Tinggi Negara- Melangkau Tahun 2020). Putrajaya: Ministry of Higher Education, August 2007.

MOE (2001). International academic advisory panel third meeting, Singapore. Press Release January 2001.

MOE. (2000). Government accepts recommendations on university governance and funding. Press Release, July 3 , Singapore.

MOE. (2009). Registering External Degree Progrmmes (EDPS).

MOE. (2010). National Education Policy. Ministry of Education, Government of Bangladesh,

MOK, K. H. (2008). Positioning as regional hub for Higher Education: Changing Governance and Regulatory Reforms In Singapore and Malaysia. International journal of Education Reform, 17(3), 230-50.

MOK, K. H. (2011). The quest for regional hub of education: growing heterarchies, organizational hybridization, and new governance in Singapore and Malaysia. Retrieved from http://www.informaworld.com/10.1080/02680939.2010.498900

Monem, M., \& Bainamin, H. M. (2010). Higher Education in Bangladesh: Status, Issues and Prospects. Pakistan Journal of Social Science, 30(2), 293-305.

Morshidi, S. (2010). Strategic planning directions of Malaysia's higher education: University autonomy in the $\begin{array}{llll}\text { midst of political uncertainties. Higher Education, 59(4), 461-73. } & \text {. }\end{array}$ http://dx.doi.org/10.1007/s10734-009-9259-0

OECD. (2011). Review profile of Innovation in south Asia. Country profile of Innovation: Malaysia.

Peril and Promise. (2000). Higher Education in Developing Countries. Washington DC, USA: The World Bank.

Pounder, J. (1999). Institutional Performance in Higher Education: is quality a relevant concept? Quality Assurance in Education, 7(3), 56-163. http://dx.doi.org/10.1108/09684889910281719

Richardson, J. T. E. (1994). A British evaluation of the Course Experience Questionnaire. Studies in Higher Education, 19, 59-68. http://dx.doi.org/10.1080/03075079412331382143

Singapore Agency for Science, Technology \& Research (A*STAR). (2001-09). National Survey of R\&D in 
Singapore. Singapore: Agency for Science, Technology \& Research

SPRING, Singapore Productivity \& Innovation Board. (2004). New initiatives in education excellence framework to boost global schoolhouse program.

Susan S. (2008). Rethinking Human Capital in Education: Singapore as A Model for Teacher Development. Paper Prepaered for the Aspen Institute Education and Society Program.

Tam, M. (2001). Measuring Quality and performance in Higher Education. Quality in Higher Education, 7(1), 47-54. http://dx.doi.org/10.1080/13538320120045076

U.S. Department of Education (2006). Accreditation in the United States, National Recognition of Accrediting Agencies by the U.S. Secretary of Education. Washington, DC: U.S. Department of Education.

UNESCO. (2005). Guidelines for Quality Provision in Cross-border Higher Education. Paris: UNESCO Publishing.

UNESCO. (2006). Higher education in South-East Asia. The UNESCO Asia and pacific regional bureau for education, Bangkok, Thailand.

University Grants Commission (UGC) of Bangladesh. (2006). Annual Report. Dhaka: UGC Publication No.116.

UNSCO. (2011). Golbal Education Digest. UNESCO Institute for Statistics Montreal, Canada.

Vikie. S. (2008). Assuring Quallity in Higher Education: Key Issues and Questions for changing Accerediation in the United States. Issue paper. A National Dialogue.

Warglien, M., \& Savoia, M. (2006). Institutional Experiences of Quality Assessment inHigher Education - The University of Venice (Italy). Organization for Economic Cooperationand Development (OECD). Retrieved from http://www.oecd.org/dataoecd/48/49/1871205.pdf

Wong, P. K., Ho, Y. P., \& Singh, A. (2006). Survey of Innovation, Intellectual Property Creation and Usage among Singapore Firms. Singapore: IP Academy.

World Bank. (2007). Cross-border tertiary education, A way toward capacity development.

World Conference on Higher Education. (2009). Trends in global Higher education: Tracking on Academic revolution. A report prepared for UNESCO.

Yeo, R. K. (2008). Brewing service quality in higher education, Characteristics of gradients that make up the recipes. Quality Assurance in Education, 16(3), 266-286. http://dx.doi.org/10.1108/09684880810886277

\section{Websites}

www.unesco.org

www.qaa.ac.uk

www.auqu.edu.au

www.ugc.ac.in

www.heqep-ugc.gov.bd

www.worldbank.org/kam.

www.international.ac.uk/resources/ 